\title{
Factors associated with undernutrition among children with sickle cell disease attending the sickle cell clinic in Mulago National Referral Hospital, Uganda
}

Rosta Asiimwe ( $\nabla$ rostaasiimwe@gmail.com )

Ernest Cook Ultrasound Research and Education Institute https://orcid.org/0000-0001-9172-022X

Rornald Muhumuza Kananura

Makerere University, School of Public Health

Richard Kajjura

Makerere University School of Public Health

Adoke Yeka

Makerere University School of Public Health

Research article

Keywords: Sickle cell disease; Undernutrition; Children; Uganda

Posted Date: October 9th, 2019

DOI: https://doi.org/10.21203/rs.2.12659/v2

License: () (1) This work is licensed under a Creative Commons Attribution 4.0 International License. Read Full License 


\section{Abstract}

Background Sickle cell disease (SCD) is among the neglected non-communicable diseases, which significantly contributes to early childhood mortality. In Uganda, over 20,000 children are estimated to be sicklers. Undernutrition is common among children with SCD and contributes to increased morbidity and mortality. There is paucity of data on prevalence of undernutrition and associated factors in Uganda. Objective To assess the extent of undernutrition and related factors among children aged 5-12 years with SCD attending the sickle cell clinic at Mulago hospital, Uganda. Methods A total of 263 children with SCD attending the sickle cell clinic at Mulago National Referral hospital were recruited consecutively between May and June 2017. The nutritional status of the children was assessed by weight-for-age, BMI-for-age, and height-for-age z-scores calculated using STATA in accordance with WHO 2007 growth standards. Binomial regression was conducted to assess the predictors of undernutrition. Results About $20.2 \%, 11.4 \%$, and $13.7 \%$ of the children were underweight, wasted and stunted respectively. Wasting was significantly associated with older age (10-12 years) ( $\mathrm{AOR}=4.20, \mathrm{Cl}=2.18-8.10)$ and living in a female headed household ( $A O R=0.43, \mathrm{Cl}=0.19-0.99)$. Stunting was significantly associated with older age (10-12 years) $(\mathrm{AOR}=2.90, \mathrm{Cl}=1.39-6.06)$. Underweight was significantly associated with older age (10-12 years) ( $\mathrm{AOR}=2.23, \mathrm{Cl}=1.05-5.16)$. Conclusion Underweight, wasting and stunting were prevalent among children with SCD attending Mulago hospital. The factors associated with undernutrition were older age and living in a female headed household.

\section{Background}

Sickle cell disease (SCD) remains a major neglected tropical disease in Africa(1). The disease is a genetic disorder that affects the shape of haemoglobin in the red blood cell leading to formation of a sickle shape(2). The sickle shape contributes to co-morbidities through the life time including pulmonary hypertension, stroke, organ damage, gall bladder disease and premature mortality(3). Globally, 250,000 out of 300,000 infants born with haemoglobin disorders every year have SCD(1). Furthermore, an estimated 240,000 children in low and middle income countries are born with SCD annually of which $50 \%-80 \%$ die before the age of five years(2). In Uganda, about 20,000 children are born with SCD every year(4). This could be an under estimate since majority of the children are not tested in most districts in the country(5).

Several nutrient deficiencies have been reported among children with SCD and this greatly affects their quality of life(6).Undernutrition(stunting, underweight and wasting) are a common occurrence among children with SCD in Africa(6-8).

SCD has been known to cause undernutrition by increased metabolic demands, chronic and acute vaso-occlusions, poor appetite and compromised absorption(8).Other factors that influence undernutrition among children with SCD include: being a male, older age, household income, duration of exclusive breastfeeding, average weight during childhood, average number of hospitalization, anaemia severity, geographical location (urban vs. rural), history of hand and foot syndrome, more than two sickle cell crises a year, medical history of severe infections and presence of hepatomegaly(7).

Previous studies on undernutrition in children with SCD have focused on the prevalence of the condition however data on the factors associated in developing countries is scarce $(7,9-11)$. The objective of this study was to assess the prevalence and factors associated with undernutrition among children with sickle cell disease attending the sickle cell clinic in Mulago National Referal Hospital (MNRH), Uganda.

\section{Methods}

This was a hospital based cross-sectional study conducted among 270 children with SCD who were attending the sickle cell clinic in MNRH from May to June 2017. MNRH is a tertiary hospital and serves as a national center for managing cases with SCD. On average it manages 800 sickle cell patients from across the country each month. We consecutively sampled confirmed cases of SCD aged 5-12 years attending the outpatient clinic whose caretakers provided consent to participate in the study. Recruitment of study participants was conducted as they waited for their monthly routine medical care. Very ill eligible children who needed hospitalization were excluded.

\section{Sample size}

The sample size was determined using the formula for single proportion by Kish Leslie, 1969.

Where: $\mathrm{n}=$ sample size; $\mathbf{z}=\mathrm{z}$ value corresponding to $95 \%$ confidence interval $=1.96 ; \mathrm{p}=$ proportion of malnutrition among SCD children $=22.7 \%(8)=0.227$; (8) $q=(1-p)=(1-0.227)=0.773=$ absolute precision $=5 \%$. Therefore, from the above formula sample size was 270.

A structured interview administered questionnaire was used to collect child weight, height, socio-demographic, co-morbidities, food intake, and household characteristics information from caretakers.

Weight of the children was measured in kilograms using a calibrated Seca 874 electronic weighing scale (9).The children were requested to take off their shoes and heavy garments and asked to stand in the middle of the platform to evenly distribute the weight to both feet(10). The weight was recorded to the nearest $0.1 \mathrm{~kg}$.

Height was measured in centimeters using a stadiometer. Children were asked to remove their shoes, hair ornaments and stand erect with the back to the stadiometer. With the back of the head, upper back, buttocks, back of the legs and heels in contact with the board, relaxed arms and the eyes looking horizontally, the head piece of the stadiometer was lowered so that the hair (if present) was pressed flat, height was recorded to the nearest $0.1 \mathrm{~cm}$.

\section{Study variables}


The dependent variable in this study was under nutrition (wasting, underweight and stunting) measured by <-2 Z-scores of BMI-for-age, weight-for-age and height-for-age anthropmetric indices respectively.

The independent variables were categorized into child characteristics and caretaker / household characteristics.

The child characteristics included: age (5-9 years and 10-12 years), sex (male, female), birth order ( $1^{\text {st }}, 2^{\text {rd }}-3^{\text {rd }}, 4^{\text {th }}$ and above), morbidities experienced in the past two weeks before the study (Acute respiratory infection, fever and diarrhea) and food intake. Food intake was assessed using the validated dietary diversity score which was based on the 10 food groups consumed in the past twenty-four hours prior to the study(11). For each of the food groups consumed, a child was awarded a score of one or zero if the food group was consumed or not consumed respectively. A dietary diversity score (DDS) cut-off was constructed to describe the dietary diversity with a sum of 0-3 as inadequate DDS and 4-10 as adequate DDS score(11).

The care taker/ household characteristics included: Age of care taker (20-24, 25-29, 30-34 and above 35 years), marital status(married/living together, not married), highest level of education (primary, O level, A level, tertiary and university), main occupation(salaried worker, business, labourer, peasant farmer, house wife and other), sex of household head (male headed, female headed), number of children (1-2, 3-4, 5 and above), average household size and household wealth index. Household wealth was computed using the principal component analysis. The variables considered were obtained using questions in the 2016 Uganda Health Demographic Survey regarding asset and access variables namely: owning: 1) a radio, 2) a television, 3) mobile phone, 4) a bicycle, 5) a motorcycle, 6) a motor vehicle, 7) a piece of land, 8) large farm animals like cattle, goats and sheep, 9) small farm animals like poultry, 10) a manufactured bed, and 11) the nature of the house(12). Household wealth index was ranked into two quintiles from the lowest to the highest (1=Low and 2=Highest).

\section{Data analyses}

Data was exported from excel to stata14.0 for analysis (Statacorp, 2015). Socio demographic data was summarized using descriptive statistics like proportions and frequencies for categorical variables and mean and standard deviations for continuous variables as appropriate. Anthropometric measurements of height and weight were used to determine undernutrition(9). Height and age were converted from centimeters to meters and years to months respectively. Body Mass Index (BMI) was calculated then the BMI for age z-scores, weight for age z-scores and height for age z-scores were computed using the WHO reference growth standards. Normal nutritional status was defined as z-scores $\geq-2$ and undernutrition (underweight, wasting and stunting) was defined as $z$-sores $<-2$. The prevalence of underweight stunting and wasting was expressed in percentages.

In order to ascertain the factors that were associated with undernutrition we started with univariable and bivariable analysis. The factors that had a potential for being considered in the multivariable model were variables found to be statistically significant at bivariable level, factors with a P-value of $<0.2$ and the insignificant variables which were deemed to be important in influencing undernutrition according to literature. We later performed multivariable analysis using binary logistic regression approach controlling for factors identified under bivariable analysis and literature. The strength of the association between variables was determined using odds ratios, P-values (a set at $<0.05$ ) and $95 \%$ confidence interval. Models were built using the stepwise regression method. Confounding was checked by observing whether variables included in the model caused a change in the odds ratio of the main exposure by at least $10 \%$. Also confounding was checked by assessing whether variables that were insignificant at bivariable stage became significant at the multivariable level. Variables in a model that were found consistently insignificant and did not add any value in terms of goodness of fit were eliminated. The model goodness of fit was tested using Hosmer-Lemeshow goodness of fit test.

\section{Results}

From the total of 270 child care-taker pairs recruited, only 263 child-caretaker pairs were included in the final analysis because some were outliers according to the WHO anthropometric indicator cut-offs. The mean age of the children was eight years (SD \pm 2$)$ and majority $66.5 \%(175 / 263)$ were in the age group $5-9$ years (Table 1). A small proportion of the children had other morbidities in the past 2 weeks including acute respiratory infection $49.1 \%(129 / 263)$, fever $41.4 \%$ $(109 / 263)$ and diarrhea $17.9 \%(47 / 263)$.

Table 1: Characteristics of study participants

\begin{tabular}{lll}
\hline Child Characteristics & Frequency (n=263) & Percent \\
\hline Age (Years) & 175 & \\
5-9 & 88 & 66.5 \\
10-12 & & 33.5 \\
Sex & 126 & \\
Male & & 47.9 \\
Dietary Diversity Score & 134 & \\
Inadequate & 129 & 50.9 \\
Adequate & & 49.1 \\
Birth order & 74 & \\
$1^{\text {st }}$ & 121 & 28.1 \\
$2^{\text {nd_-3rd }}$ & 68 & 46.0 \\
$4^{\text {th and above }}$ & & 25.9 \\
Morbidities in the past two weeks & 129 & \\
Acute respiratory infection (ARI) & 129.1 \\
Fever & 109 & 41.4 \\
Diarrhea & 47 & 17.9 \\
\hline
\end{tabular}


The social demographic characteristics of the caretakers are shown in table 2. The mean age of caretakers was 33 years (SD8years). Majority $70.3 \%$ $(185 / 263)$ of the caretakers were married, and about half $45.6 \%(120 / 263)$ had attained secondary education. Majority $73.0 \%$ (193/263) of the respondents came from male headed households. The average household size was 5 people (SD2 people).

Table 2: Characteristics of the caretakers and their households

\begin{tabular}{|c|c|c|}
\hline Care taker characteristics & Frequency $(n=263)$ & Percent (\%) \\
\hline \multicolumn{3}{|l|}{ Caretaker Age (years) } \\
\hline $20-24$ & 23 & 8.8 \\
\hline $25-29$ & 65 & 24.7 \\
\hline $30-34$ & 75 & 28.5 \\
\hline$\geq 35$ & 100 & 38.0 \\
\hline \multicolumn{3}{|l|}{ Current marital status } \\
\hline Married/Living together & 185 & 70.3 \\
\hline Not married & 78 & 29.7 \\
\hline \multicolumn{3}{|c|}{ Highest Level of education } \\
\hline Primary & 92 & 35.0 \\
\hline O' level & 105 & 39.9 \\
\hline $\mathrm{A}^{\prime}$ level & 15 & 5.7 \\
\hline Tertiary & 33 & 12.6 \\
\hline University & 18 & 6.8 \\
\hline \multicolumn{3}{|l|}{ Main Occupation } \\
\hline Salaried worker & 40 & 15.2 \\
\hline Business & 91 & 34.6 \\
\hline Labourer & 10 & 3.8 \\
\hline Peasant farmer & 20 & 7.6 \\
\hline Housewife & 71 & 27.0 \\
\hline Other & 31 & 11.8 \\
\hline \multicolumn{3}{|l|}{ Sex of household head } \\
\hline Male headed & 193 & 73.4 \\
\hline Female headed & 70 & 26.6 \\
\hline \multicolumn{3}{|l|}{ Number of children } \\
\hline $1-2$ & 76 & 28.9 \\
\hline $3-4$ & 127 & 48.3 \\
\hline 5 and above & 60 & 22.8 \\
\hline \multicolumn{3}{|l|}{ Average household size } \\
\hline \multicolumn{2}{|l|}{ Wealth index } & \\
\hline Lowest & 87 & 33.1 \\
\hline Middle & 88 & 33.4 \\
\hline Highest & 88 & 33.5 \\
\hline
\end{tabular}

\section{Prevalence of wasting, stunting and underweight}

The children's weight ranged from $14.2-46.0 \mathrm{~kg}$, height ranged from $100.9-157.6 \mathrm{~cm}$, and BMI ranged from $12.1-20.1 \mathrm{~kg} / \mathrm{m}^{2}$. Mean z-sores for wasting, stunting and underweight were $-1.08 \pm 1.07,-0.81 \pm 1.07$ and $0.81 \pm 1.02$ respectively. About $11.4 \%(30 / 263)$ were wasted $13.7 \%$ (36/263) were stunted, while20.2\% (53/263) of the children were underweight; details are shown in table 3.

Table 3: Nutrition status of study participants

\begin{tabular}{llll}
\hline Variable & Mean \pm SD & Frequency $(\mathbf{n = 2 6 3 )}$ & Percentage (\%) \\
\hline Weight $(\mathrm{kg})$ & $22.75 \pm 5.68$ & - & - \\
Height $(\mathrm{cm})$ & $122.12 \pm 12.39$ & - & - \\
BMI $\left(\mathrm{kg} / \mathrm{m}^{2}\right)$ & $15.04 \pm 1.39$ & - & - \\
z-sores for wasting & $-1.08 \pm 1.07$ & - & - \\
z-sores for stunting & $-0.80 \pm 1.16$ & - & - \\
z-sores for underweight & $0.81 \pm 1.02$ & - & - \\
Wasting & - & 30 & 11.4 \\
Stunting & - & 36 & 13.7 \\
Underweight & - & 53 & 20.2 \\
\hline
\end{tabular}

Factors associated with wasting of study participants. 
Wasting was significantly associated with age of the child and sex of household head (Table 4). Children aged 10-12 years were more likely to be wasted compared to their counterparts $(\mathrm{AOR}=4.27, \mathrm{Cl}=2.20-8.29)$. Additionally, children who were born in female headed households were less likely to be wasted compared to those born in male headed households ( $\mathrm{AOR}=0.39, \mathrm{Cl}=0.16-0.92)$.

Table 4: Factors associated with wasting of study participants

\begin{tabular}{|c|c|c|c|c|c|c|}
\hline \multirow[t]{2}{*}{ Characteristics } & \multicolumn{2}{|c|}{ Wasted } & \multirow[b]{2}{*}{$\begin{array}{l}\text { Crude OR } \\
(95 \% \mathrm{CI})\end{array}$} & \multirow[b]{2}{*}{$P$ value } & \multirow[b]{2}{*}{$\begin{array}{l}\text { Adjusted OR } \\
(95 \% \mathrm{CI})\end{array}$} & \multirow[b]{2}{*}{$P$ value } \\
\hline & $\begin{array}{l}\text { No } \\
(n=233)\end{array}$ & $\begin{array}{l}\text { Yes } \\
(n=30)\end{array}$ & & & & \\
\hline \multicolumn{7}{|c|}{ Age of child (Years) } \\
\hline $5-9$ & $161(92.0)$ & $14(8.0)$ & 1.00 & & 1.00 & \\
\hline $10-12$ & $72(81.8)$ & $16(18.2)$ & $2.56(1.18-5.52)$ & 0.017 & $4.27(2.20-8.29)$ & $<0.01$ \\
\hline \multicolumn{7}{|l|}{ Sex of child } \\
\hline Male & 113(89.7) & $13(10.3)$ & 1.00 & & & \\
\hline Female & $120(87.6)$ & $17(12.4)$ & $1.23(0.57-2.65)$ & 0.595 & & \\
\hline \multicolumn{7}{|l|}{$\mathrm{ARI}^{\mathrm{B}}$ co morbidity } \\
\hline Yes & $114(88.4)$ & $15(11.6)$ & 1.00 & & 1.00 & \\
\hline No & $119(88.8)$ & $15(11.2)$ & $0.96(0.45-2.05)$ & 0.912 & $1.37(.699-2.698)$ & 0.36 \\
\hline \multicolumn{7}{|c|}{ Fever $^{B}$ co morbidity } \\
\hline Yes & $93(85.3)$ & $16(14.7)$ & 1.00 & & 1.00 & \\
\hline No & $140(90.9)$ & $14(9.1)$ & $0.58(0.27-1.25)$ & 0.164 & $.685(0.34-1.36)$ & 0.28 \\
\hline \multicolumn{7}{|c|}{ Diarrhea ${ }^{B}$ co morbidity } \\
\hline Yes & $41(87.2)$ & $6(12.8)$ & 1.00 & & 1.00 & \\
\hline No & $192(88.9)$ & $24(11.1)$ & $0.85(0.33-2.22)$ & 0.747 & $0.82(0.36-1.85)$ & 0.63 \\
\hline \multicolumn{7}{|c|}{ Dietary Diversity Score } \\
\hline Inadequate & $116(86.6)$ & $18(13.4)$ & 1.00 & & & \\
\hline Adequate & $117(90.7)$ & $12(9.3)$ & $0.66(0.30-1.43)$ & 0.295 & & \\
\hline \multicolumn{7}{|l|}{ Birth order } \\
\hline $1^{\text {st }}$ & $66(89.2)$ & $8(10.8)$ & 1.00 & & & \\
\hline $2^{\text {nd }}$ to $3^{\text {rd }}$ & $105(86.8)$ & $16(13.2)$ & $1.26(0.51-3.10)$ & 0.619 & & \\
\hline 4 and above & $62(91.2)$ & $6(8.8)$ & $0.80(0.26-2.43)$ & 0.692 & & \\
\hline \multicolumn{7}{|c|}{ Sex of household head } \\
\hline Male & $171(88.6)$ & $22(11.4)$ & 1.00 & & 1.00 & \\
\hline Female & $62(88.6)$ & $8(11.4)$ & $1.00(0.42-2.37)$ & 0.995 & $0.39(0.16-0.92)$ & 0.03 \\
\hline \multicolumn{7}{|c|}{ Marital status of caretaker } \\
\hline Married & $166(89.7)$ & $19(10.3)$ & 1.00 & & & \\
\hline Not married & $67(85.9)$ & $11(14.1)$ & $1.43(0.65-3.18)$ & 0.374 & & \\
\hline \multicolumn{7}{|c|}{ Number of children by caretaker } \\
\hline 1 to 2 & $68(89.5)$ & $8(10.5)$ & 1.00 & & & \\
\hline 3 to 4 & $112(88.2)$ & $15(11.8)$ & $1.14(0.46-2.83)$ & 0.780 & & \\
\hline 5 and above & $53(88.3)$ & $7(11.7)$ & $1.12(0.38-3.29)$ & 0.833 & & \\
\hline \multicolumn{7}{|l|}{ Family size } \\
\hline$\leq 5$ people & $147(90.7)$ & $15(9.3)$ & 1.00 & & 1.00 & \\
\hline$>5$ people & $86(85.2)$ & $15(14.8)$ & $1.71(0.80-3.67)$ & 0.169 & $1.71(0.89-3.30)$ & 0.109 \\
\hline \multicolumn{7}{|l|}{ Wealth index } \\
\hline Low & $112(48.1)$ & $20(66.7)$ & 1.00 & & 1.00 & \\
\hline High & $121(51.9)$ & $10(33.3)$ & $0.46(0.21-1.03)$ & 0.060 & $077(0.39-1.54)$ & 0.46 \\
\hline
\end{tabular}

B=Illnesses experienced by child two weeks prior to study

\section{Factors associated with stunting of study participants}

In the present study stunting was independently associated with age of the child as shown in Table 5 . Children aged 10-12 years were more likely to be stunted compared to their counterparts ( $\mathrm{AOR}=2.90, \mathrm{Cl}=1.39-6.06)$.

Table 5: Factors associated with stunting of study participants 


\begin{tabular}{|c|c|c|c|c|c|c|}
\hline \multirow[t]{2}{*}{ Characteristics } & \multicolumn{2}{|c|}{ Stunted } & \multirow[b]{2}{*}{$\begin{array}{l}\text { Crude OR } \\
(95 \% \mathrm{CI})\end{array}$} & \multirow[b]{2}{*}{$P$ value } & \multirow[b]{2}{*}{$\begin{array}{l}\text { Adjusted OR } \\
(95 \% \mathrm{CI})\end{array}$} & \multirow[b]{2}{*}{$P$ value } \\
\hline & $\begin{array}{l}\text { No } \\
(n=227)\end{array}$ & $\begin{array}{l}\text { Yes } \\
(n=36)\end{array}$ & & & & \\
\hline \multicolumn{7}{|l|}{ Age of child } \\
\hline 5-9years & $159(90.9)$ & $16(9.1)$ & 1.00 & & 1.00 & \\
\hline 10-12years & $68(77.3)$ & $20(22.7)$ & $2.92(1.43-5.98)$ & 0.003 & $2.90(1.39-6.06)$ & 0.005 \\
\hline \multicolumn{7}{|l|}{ Sex of child } \\
\hline Male & $111(88.1)$ & 15(11.9) & 1.00 & & & \\
\hline Female & $116(84.7)$ & $21(15.3)$ & $1.34(0.66-2.73)$ & 0.420 & & \\
\hline \multicolumn{7}{|c|}{ Child experienced ARI ${ }^{B}$} \\
\hline Yes & $114(88.4)$ & $15(11.6)$ & 1.00 & & & \\
\hline No & $113(84.3)$ & $21(15.7)$ & $1.41(0.69-2.88)$ & 0.342 & & \\
\hline \multicolumn{7}{|c|}{ Child experienced Fever ${ }^{B}$} \\
\hline Yes & $92(84.4)$ & $17(15.6)$ & 1.00 & & & \\
\hline No & $135(88.7)$ & $19(12.3)$ & $0.76(0.38-1.54)$ & 0.450 & & \\
\hline \multicolumn{7}{|c|}{ Child experienced Diarrhea ${ }^{B}$} \\
\hline Yes & $39(83.0)$ & $8(17.0)$ & 1.00 & & & \\
\hline No & $188(87.0)$ & 28(13.0) & $0.73(0.31-1.71)$ & 0.465 & & \\
\hline \multicolumn{7}{|c|}{ Child Dietary Diversity Score } \\
\hline Inadequate & $116(86.6)$ & $18(13.4)$ & 1.00 & & & \\
\hline Adequate & $111(86.1)$ & 18(13.9) & $1.05(0.52-2.11)$ & 0.902 & & \\
\hline \multicolumn{7}{|c|}{ Child birth position } \\
\hline $1^{\text {st }}$ & $64(86.5)$ & $10(13.5)$ & 1.00 & & & \\
\hline 2 nd to $3^{\text {rd }}$ & $104(86.0)$ & $17(14.0)$ & $1.05(0.45-2.43)$ & 0.916 & & \\
\hline $4^{\text {th }}$ and above ${ }^{\mathrm{h}}$ & $59(86.8)$ & $9(13.2)$ & $0.98(0.37-2.57)$ & 0.961 & & \\
\hline \multicolumn{7}{|c|}{ Sex of household head } \\
\hline Male & $164(85.0)$ & $29(15.0)$ & 1.00 & & 1.00 & \\
\hline Female & $63(90.0)$ & $7(10.0)$ & $0.63(0.26-1.51)$ & 0.298 & $0.41(0.13-1.28)$ & 0.124 \\
\hline \multicolumn{7}{|c|}{ Marital status of caretaker } \\
\hline Married & $160(86.5)$ & $25(13.5)$ & 1.00 & & 1.00 & \\
\hline Not married & $67(85.9)$ & $11(14.1)$ & $1.05(0.49-2.26)$ & 0.899 & $1.80(0.66-4.89)$ & 0.254 \\
\hline \multicolumn{7}{|c|}{ Number of children by caretaker } \\
\hline $1-2$ & $70(92.1)$ & $6(7.9)$ & 1.00 & & 1.00 & \\
\hline 3 to 4 & $107(84.3)$ & $20(15.7)$ & $2.18(0.83-5.70)$ & 0.112 & $1.92(0.71-5.19)$ & 0.196 \\
\hline 5 and above & $50(86.3)$ & $10(13.7)$ & $2.33(0.80-6.84)$ & 0.122 & $1.85(0.60-5.71)$ & 0.283 \\
\hline \multicolumn{7}{|l|}{ Family size } \\
\hline$\leq 5$ people & $140(86.4)$ & $22(13.6)$ & 1.00 & & & \\
\hline$>5$ people & $87(86.1)$ & $14(13.9)$ & $1.02(0.50-2.11)$ & 0.949 & & \\
\hline \multicolumn{7}{|l|}{ Wealth index } \\
\hline Low & $111(48.9)$ & $21(58.3)$ & 1.00 & & & \\
\hline High & $116(51.1)$ & $15(41.7)$ & $0.80(0.43-1.46)$ & 0.46 & & \\
\hline
\end{tabular}

Factors associated with underweight of study participants

Underweight was associated with age of the child and household wealth index (Table 6). Children aged 10-12 years were more likely to be underweight compared to their counterparts ( $\mathrm{AOR}=2.23, \mathrm{Cl}=1.05-5.16)$.

Table 6: Factors associated with underweight of study participants 


\begin{tabular}{|c|c|c|c|c|c|c|}
\hline \multirow[t]{2}{*}{ Characteristics } & \multicolumn{3}{|c|}{ Underweight } & \multirow[b]{2}{*}{$P$ value } & \multirow[b]{2}{*}{$\begin{array}{l}\text { Adjusted OR } \\
(95 \% \mathrm{CI})\end{array}$} & \multirow[b]{2}{*}{$P$ value } \\
\hline & $\begin{array}{l}\text { No } \\
(n=210)\end{array}$ & $\begin{array}{l}\text { Yes } \\
(n=53)\end{array}$ & $\begin{array}{l}\text { Crude OR } \\
(95 \% \text { CI })\end{array}$ & & & \\
\hline \multicolumn{7}{|l|}{ Age of child } \\
\hline 5-9years & $154(88.0)$ & $21(12.0)$ & 1.00 & & 1.00 & \\
\hline 10-12years & $56(63.6)$ & $32(36.4)$ & $4.19(2.23-7.87)$ & $<0.001$ & $2.2(1.03-5.02)^{*}$ & $<0.001$ \\
\hline \multicolumn{7}{|l|}{ Sex of child } \\
\hline Male & $101(80.2)$ & $25(19.8)$ & 1.00 & & & \\
\hline Female & $109(79.6)$ & $28(20.4)$ & $1.04(0.57-1.90)$ & 0.904 & & \\
\hline \multicolumn{7}{|c|}{$\mathrm{ARI}^{\mathrm{B}}$ co morbidity } \\
\hline Yes & $103(79.8)$ & $26(20.2)$ & 1.00 & & & \\
\hline No & $107(79.9)$ & $27(20.1)$ & $1.00(0.55-1.83)$ & 0.999 & & \\
\hline \multicolumn{7}{|c|}{ Fever $^{B}$ co morbidity } \\
\hline Yes & $82(75.2)$ & $27(24.8)$ & 1.00 & & 1.00 & \\
\hline No & $128(83.1)$ & 26(16.9) & $0.62(0.34-1.13)$ & 0.118 & $0.66(0.30-1.44)$ & 0.289 \\
\hline \multicolumn{7}{|c|}{ Diarrhea ${ }^{\mathrm{B}}$ co morbidity } \\
\hline Yes & $36(76.6)$ & $11(23.4)$ & 1.00 & & & \\
\hline No & $174(80.6)$ & $42(19.4)$ & $0.79(0.37-1.68)$ & 0.540 & & \\
\hline \multicolumn{7}{|c|}{ Dietary Diversity Score } \\
\hline Inadequate & 108(80.6) & $26(19.4)$ & 1.00 & & & \\
\hline Adequate & $102(79.1)$ & $27(20.9)$ & $1.10(0.60-2.01)$ & 0.785 & & \\
\hline \multicolumn{7}{|l|}{ Birth position } \\
\hline $1^{\text {st }}$ & $62(83.8)$ & $12(16.2)$ & 1.00 & & & \\
\hline $2^{\text {nd }}$ to $3^{\text {rd }}$ & $92(76.0)$ & $29(24.0)$ & $1.63(0.77-3.43)$ & 0.200 & & \\
\hline $4^{\text {th }}$ and above & $56(82.4)$ & $12(17.6)$ & $1.11(0.46-2.66)$ & 0.820 & & \\
\hline \multicolumn{7}{|c|}{ Sex of household head } \\
\hline Male & $149(77.2)$ & $44(22.8)$ & 1.00 & & 1.00 & \\
\hline Female & $61(87.1)$ & $9(12.9)$ & $0.50(0.23-1.09)$ & 0.08 & $0.67(0.21-2.10)$ & 0.048 \\
\hline \multicolumn{7}{|c|}{ Caretaker Marital status } \\
\hline Married & $148(80.0)$ & $37(20.0)$ & 1.00 & & 1.00 & \\
\hline Not married & $62(79.5)$ & $16(20.5)$ & $1.03(0.53-1.99)$ & 0.925 & $1.81(0.62-5.27)$ & \\
\hline \multicolumn{7}{|c|}{ Number of children by caretaker } \\
\hline 1 to 2 & $66(86.8)$ & $10(13.2)$ & 1.00 & & & \\
\hline 3 to 4 & $101(79.5)$ & $26(20.5)$ & $1.70(0.77-3.75)$ & 0.190 & & \\
\hline 5 and above & $43(71.7)$ & $17(28.3)$ & $2.61(1.09-6.23)$ & 0.031 & & \\
\hline \multicolumn{7}{|l|}{ Family size } \\
\hline$\leq 5$ people & $137(84.6)$ & $25(15.4)$ & 1.00 & & 1.00 & \\
\hline$>5$ people & $73(72.3)$ & $28(27.7)$ & $2.10(1.14-3.87)$ & 0.017 & $1.60(0.72-3.58)$ & 0.129 \\
\hline \multicolumn{7}{|l|}{ Wealth index } \\
\hline Low & $103(78.0)$ & $29(22.0)$ & 1.00 & & & \\
\hline High & $107(81.7)$ & $24(18.3)$ & $0.80(0.43-1.46)$ & 0.461 & & \\
\hline
\end{tabular}

$\mathbf{B}_{=}$Illnesses experienced by child two weeks prior to study

\section{Discussion}

The aim of the study was to assess the factors associated with undernutrition in children with SCD aged 5-12 years attending the sickle cell clinic in MNRH. The findings revealed that older age (10-12 years) and living in a female headed household were significantly associated with undernutrition.

In this study about $20.2 \%, 11.4 \%$, and $13.7 \%$ of the children were underweight, wasted and stunted respectively. This shows that undernutrition was prevalent among children with SCD according to the WHO categorisation (13). Undernutrition has a negative impact on the quality of life of children with SCD (14). Evidence from a cohort study conducted in Tanzania reported an increased risk of hospitalisation with undernutrition among patients with SCD particularly with wasting (15).

A prevalence of $20.2 \%$ was reported for underweight in this study. Similar observations were made in a recent study conducted in Accra (16). On the other hand high prevalence's have been reported for example in Tanzania (36.2\%) (15). This might be explained by the difference in age groups of the study participants that is five to twelve years in the present study versus 0.5 to 48 years in the Tanzanian study which did not look at the prevalence for the children separately. Wasting was found in $11.4 \%$ of the children with SCD. The prevalence of wasting among children with SCD in other studies ranges between $18.4 \%$ to $50.3 \%(15,17,18)$. Height for age was low in $13.7 \%$ of the children with SCD. A similar study conducted in Democratic Republic of Congo among children aged $0-12$ years reported stunting at $10.5 \%$ (17). This is comparable to the finding of the present study probably because both studies were conducted in the major sickle cell centers in the main cities.

\subsection{Factors associated with undemutrition}

Results for this study showed that older children aged between ten to twelve years were more likely to be underweight, stunted and wasted compared to the younger ones. Among children with SCD delay in growth starts early in childhood but becomes more obvious as the child grows up (19). This is likely attributed to increased demand for nutrients for growth, fighting off the recurrent infections and a lack of appetite(14). Findings are similar to other studies conducted in Philadelphia and Yemen that have reported the same trend among children with SCD $(12,16)$. For instance evidence from a longitudinal study by 
Zemel et al (2010) reported that the height status decreased with advancement in age among patients with SCD but more especially during puberty. Thus a balanced diet should be emphasized in the older children through nutrition education of all family members.

\section{Limitations}

The study was cross sectional in nature so no casual relationships can be concluded on due to lack of a temporal relationship between the predictors and nutritional status. Additionally some predictors related to the management of SCD and other comorbidities were not included in this study.

\section{Generalisability}

The generalisability of the results in this study is limited to children with SCD attending a health service setting.

\section{Conclusion}

In conclusion, undernutrition was prevalent among the children with SCD. The factors associated with under nutrition were older age (10-12 years) and living in a female headed households. Interventions like skills based nutrition education integrating older children and enhancement of women's control of household resources by improvement of social economic status of caretakers through business trainings and providing vocational skills can improve under nutrition in children with SCD.

\section{List Of Abbreviations}

\begin{tabular}{ll} 
ARI & Acute Respiratory Infection \\
\hline BMI & Body Mass Index \\
\hline DDS & Dietary Diversity Score \\
SCD & Sickle Cell Disease \\
\hline SD & Standard Deviation \\
\hline WHO & World Health Organisation \\
\hline MNRH & Mulago National Referral Hospital
\end{tabular}

\section{Declarations}

\section{Ethics approval and consent to participate}

Ethical approval to conduct the study was sought from Makerere University School of Public Health Higher Degrees Research and Ethics Committee. Furthermore, permission was also sought from Mulago Hospital Research and Ethics Committee (MREC1152). Details of the study were explained to the Head of Department and caretaker's written consent was obtained from the participating caretakers. Care takers were interviewed individually for privacy and personal information was kept confidential by using identification numbers.

\section{Consent for publication}

Not applicable

\section{Availability of data and materials}

The datasets used and/or analyzed during the current study are available from the corresponding author on reasonable request.

\section{Competing interests}

The authors declare that they have no competing interest.

\section{Funding}

This research was funded by Mr. Issa Katwesige and Mr. George Kacha Kaija. These individuals did not have any influence in the design of study, data collection, analysis, interpretation of data and writing of the manuscript.

\section{Authors' contributions}

AR, RMK, RK and AY conceived, designed, and revised the manuscript. AR and AY made the literature search. AR and RMK did the statistical analysis. All authors read and approved the final manuscript.

\section{Acknowledgements}

The authors are grateful to the children, parents/ care takers and staff of the sickle cell clinic of Mulago National Referral Hospital who participated in this study. We also want to thank the research assistants who collected the data. 


\section{References}

1. Piel FB, Patil AP, Howes RE, Nyangiri OA, Gething PW, Dewi M, et al. Global epidemiology of sickle haemoglobin in neonates: a contemporary geostatistical model-based map and population estimates. The Lancet. 2013 Jan 12;381(9861):142-51.

2. Piel FB, Hay SI, Gupta S, Weatherall DJ, Williams TN. Global burden of sickle cell anaemia in children under five, 2010-2050: modelling based on demographics, excess mortality, and interventions. PLoS Med. 2013;10(7):e1001484.

3. Schnog JB, Duits AJ, Muskiet FA, Ten Cate H, Rojer RA, Brandjes DP. Sickle cell disease; a general overview. Neth J Med. 2004;62(10):364-74.

4. Ndeezi G, Kiyaga C, Hernandez AG, Munube D, Howard TA, Ssewanyana I, et al. Burden of sickle cell trait and disease in the Uganda Sickle Surveillance Study (US3): a cross-sectional study. Lancet Glob Health. 2016;4(3):e195-e200.

5. Okwi AL, Byarugaba W, Ndugwa CM, Parkes A, Ocaido M, Tumwine JK. An up-date on the prevalence of sickle cell trait in Eastern and Western Uganda. BMC Hematol. 2010;10(1):5.

6. Martyres DJ, Vijenthira A, Barrowman N, Harris-Janz S, Chretien C, Klaassen RJ. Nutrient insufficiencies/deficiencies in children with sickle cell disease and its association with increased disease severity. Pediatr Blood Cancer. 2016;63(6):1060-1064.

7. Nikhar HS, Meshram SU, Shinde GB. An anthropometric and hematological comparison of sickle cell disease children from rural and urban areas. Indian J Hum Genet. 2012;18(1):40.

8. Hyacinth HI, Gee BE, Hibbert JM. The role of nutrition in sickle cell disease. Nutr Metab Insights. 2010;3:NMI-S5048.

9. World Health Organization: WHO Child Growth Standards:... - Google Scholar [Internet]. [cited 2019 Apr 24]. Available from: https://scholar.google.com/scholar_lookup?

title=WHO\%20child\%20growth\%20standards\%3A\%20training\%20course\%20on\%20child\%20growth\%20assessment\%E2\%80\%94interpreting\%20growth\%2

10. Status WP. The use and interpretation of anthropometry. WHO Tech Rep Ser. 1995;854(9).

11. Kennedy G, Ballard T, Dop M. FAO Guidelines for Measuring Household and Individual Dietary Diversity. Rome Italy Food Agric Organ U N. 2013;

12. Statistics (UBOS) UB of, ICF. Uganda demographic and health survey 2016: key indicators report. UBOS, and Rockville Maryland; 2017.

13. Organization WH. Global Database on Child Growth and Malnutrition: Growth Reference Data for 5-19 Years. Httpwww Who Intgrowthrefen. 2007;

14. Barden EM, Zemel BS, Kawchak DA, Goran MI, Ohene-Frempong K, Stallings VA. Total and resting energy expenditure in children with sickle cell disease. J Pediatr. 2000;136(1):73-79.

15. Cox SE, Makani J, Fulford AJ, Komba AN, Soka D, Williams TN, et al. Nutritional status, hospitalization and mortality among patients with sickle cell anemia in Tanzania. haematologica. 2011,haematol-2010.

16. Boadu I, Ohemeng A, Renner LA. Dietary intakes and nutritional status of children with sickle cell disease at the Princess Marie Louise Hospital, Accra-a survey. BMC Nutr. 2018;4(1):33.

17. Lukusa Kazadi A, Ngiyulu RM, Gini-Ehungu JL, Mbuyi-Muamba JM, Aloni MN. Factors associated with growth retardation in children suffering from sickle cell anemia: First report from central Africa. Anemia. 2017;2017.

18. Al-Saqladi A-W, Bin-Gadeen HA, Brabin BJ. Growth in children and adolescents with sickle cell disease in Yemen. Ann Trop Paediatr. 2010;30(4):287-298.

19. Nandanwar RA, Kamd NY. Sickle cell disease affects physical growth. Int J Pharm Bio Sci. 2013;4(2):784-789.

20. Acham H. Nutrition, health and academic achievement of primary school children: A case of Kumi District, Eastern Uganda [PhD Thesis]. Makerere University; 2010.

21. Pryer JA, Rogers S, Rahman A. The epidemiology of good nutritional status among children from a population with a high prevalence of malnutrition. Public Health Nutr. 2004;7(2):311-317. 